\title{
ETHICS, ICONOCLASM, AND QUR'ANIC ART IN INDONESIA
}

\author{
KENNETH M. GEORGE \\ University of Wisconsin-Madison
}

“To live in any culture whatsoever," writes W. J. T. Mitchell, "is to live in a visual culture" (2005:349). The living, however, is not easy. Culture is never a settled matter, and Mitchell has been careful to remind us how our lived-in worlds find ideological and ethical shape in the predicaments and crises of image making. Taking a cue from Mitchell, I use this essay to reflect on a few episodes of panic and outrage in Indonesian Islamic visual culture. I focus in particular on the apprehensiveness, alarm, and watchful concern that surround the making of Qur'anic art.

My interests in doing so are several. First and most generally, I want to emphasize that the production and reception of Islamic art are ethical projects and never a simple, straightforward, or easy enterprise. Accordingly, this essay belongs to a growing conversation among anthropologists about Muslim ethics and politics (e.g., Asad 2003; Ewing 1997; Fischer and Abedi 1990a, 1990b; George in press; Hirschkind 2006; Hoesterey 2009; Mahmood 2005; Silverstein 2008). Indeed, looking at moments of panic, outrage, and censorship may afford us a special glimpse of varying ethicopolitical claims as to what is or is not Islamically significant in the field of visual culture. Second, we need to recognize the lively traffic in visual culture emanating from and moving through Muslim lifeworlds. That traffic is not just in motion across public spheres, but takes various forms, goes through various mediations, and mingles with various religious ideas and practices in various ways (e.g., Fischer 2004; Marcus and Myers 1995; Myers 2002; 
Thomas and Losche 1999). Third, I call attention to some of the power relations and ideologies that shape today's national and transnational Muslim art worlds, and thereby call into question popular views that expect Muslims everywhere around the globe to adhere to a uniform ethicoaesthetic sensibility mandated by a singular and inflexible religious creed. Bringing these three interests together as I do, I wish to make an ethnographic and analytic contribution to the anthropology of Islam (which has yet to deeply explore visual cultural practices); the anthropology of art (which has only recently shed its preoccupation with premodern and ethnic art); the anthropology of material culture and semiotic ideologies (where ethicopolitical struggles are especially salient); and finally, if only in passing, to Islamic art history (which has obscured many controversies over Islamic art and too often has marginalized the work of Indonesian Muslim artists).

In the pages that follow, then, I first provide some general remarks about Islamic visual culture, and then turn to Indonesia's Muslim community (or ummat) to see some of the dilemmas that have befallen painters and designers when they use Qur'anic Arabic with pictorial intent or for pictorial purposes. I start with the 1994 public outcry from the Indonesian Council of Islamic Scholars (Majelis Ulama Indonesia, or MUI) over Karl Lagerfeld's use of Qur'anic Arabic on a Chanel bustier. What Lagerfeld would learn is that a custodial ethics for displaying Qur'anic script subtends an interest in Arabic orthography from an "aesthetic point of view." Those same ethics came into play in the abstract, calligraphic paintings of Indonesian artist A. D. Pirous. Using Qur'anic Arabic as both a pictorial and verbal sign gave Pirous a way to claim religious import for what is usually regarded as a secular cultural endeavor. It also exposed him over the years to criticism from conservative ulama and gallery goers, whose particular views toward Arabic orthography made the surfaces of canvases problematic sites for rival dimensions and ideologies of word and image. By bringing both the pious and sacrilegious use of Qur'anic Arabic by artists into comparative view, I wish to throw light on some of the ethical and ideological energies that animate some contemporary Muslim art publics. ${ }^{1}$ Last, I briefly place these Indonesian anxieties and energies into comparative light with the cultural politics of Arabic in the Middle East and elsewhere. I do so, in part, to relativize and complicate rigid ideological views toward Qur'anic Arabic and toward Arabic language and orthography more generally. In keeping with that goal, I adhere in this essay to Indonesian spellings of Arabic words that are already part of everyday Indonesian discourse. 


\section{ISLAMIC VISUAL CULTURE}

"Like other religions," remarks Aziz Al-Azmeh, "Islam is not a generic essence but a nominal entity that conjoins, by means of a name, a variety of societies, cultures, histories, and polities" (1993:60). The same is true of "Islamic visual culture." It is a field characterized by aspiration, debate, experiment, and constraint, rather than allegiance to a settled set of aesthetic principles. It has roots in, and has dropped its fruit on, a broad range of social, cultural, historical, and political circumstances. For this reason we need to turn our scholarship against universalist notions of "Islamic aesthetics" to discover how the traffic in art and the discourses of the visual historically have come into view in Muslim communities and public spheres and how they have mingled with religious ideas and practices (cf. Fischer 2004, 2009). For example, Muslims and Muslim communities are often pictured as unwaveringly aniconic (avoiding images), iconophobic (afraid of images), or iconoclastic (denouncing or destroying images), especially when it comes to human figures and figuration, or pictures of living things. Yet iconoclasm in Islamic communities, like iconoclasm in Western and largely Christian contexts, typically springs from crises and changes in politics and rule. As Finbarr Barry Flood has so succinctly put it, there is no "timeless theology of images" in Islamic thought, but instead a rich history of "aesthetic appreciation, awe, fascination, [and] revulsion” (2002:651, 650). Muslims ceaselessly rethink and rework their arts as they respond to the shifting currents of culture, politics, and history, and as they negotiate their varied allegiances to - and identifications with - nation, ethnicity, kin, and ideology. We would do well, then, to refrain from drawing rigid territorial or ideological borders around visual cultures in Muslim communities and networks, presuming that they are blinkered by an unchanging and thoroughgoing homogeneity, or mistaking "Islamic art" as their only aesthetic venture. ${ }^{2}$

Southeast Asia, and Indonesia in particular, do not figure prominently in the scholarly literature on Islamic art and visual culture. Most historians of Islamic art devote their attention to works found in the Middle East, South Asia, and Africa, or to the contemporary projects emerging from the transnational and diasporic networks of Muslim artists hailing from those regions. ${ }^{3}$ There are many reasons for these emphases, including Arab centrism and the Orientalist ventures and academic legacies of European colonialism. I do not have the space to chart all the factors behind Indonesia's marginalization in the literature on Islamic art. Yet one thing should be said: Given that Indonesia is home to roughly 220 million Muslims, the place appears ripe for harvesting new understandings of pluralism and debate in Islamic visual culture. 
Debate in Indonesia about Islamic art goes back to the "cultural polemics" (polemik kebudayaan) of the nationalist era (roughly 1930-65). In these debates, questions about Islamic literature typically eclipsed concerns about Islamic visual culture. ${ }^{4}$ The manifestos and symposia of the period are vague about Islamic art. For example, the Indonesian Islamic Students (PII, Pelajar Islam Indonesia) declared in 1956: "Islam does not ban the arts, but encourages them and fills them with meaning. Islamic art is that which 'breathes' Islam” (Kratz 1986:83). Beyond asserting that art should not contravene the principles of Islam, the declarations and manifestos of the time did little to bring order to what one Minister for Religious Affairs during the 1950s called "the jungle of Islamic art and culture" (Kratz 1986:72), or to reconcile the interests of religious conservatives with the aspirations of artists. The 1970s and 1980s subsequently ushered in a new wave of interest in Islamic culture in Indonesia, as the global Islamic Awakening and the cultural policies of the Soeharto regime put into play new prospects and motivations for religious expression in the arts.

At least one Western observer harbored doubts about the influence or direction of Islamic literature and art in Indonesia up through this period. Writing in 1987, Henk Maier remarked that "Somehow, Indonesian Muslims have never been able to formulate a workable politics of culture" nor been able to "overcome the fragmentization and uncertainty within the Muslim community" (1987:10). But should we really expect unanimity, harmony, or cogent direction in the cultural aspirations of so large and diverse a community? And what sense does it make to say, as Maier does, that "Discussions about Muslim art remained restricted to the Muslim community”? (1987:10, emphasis added) when that community includes 90 percent of all Indonesian citizens? Discussion about Islamic culture in Indonesia is not a restricted discourse but an acute and widespread one, especially since the early 1990s, when the Soeharto regime began to actively promote popular religious awareness and piety. ${ }^{5}$ Liberalization of the Indonesian public sphere after the collapse of the Soeharto regime in 1998 only accelerated debate and difference within the ummat on matters of cultural and political expression. ${ }^{6}$ It is precisely in moments of panic, crisis, debate, and censorship that we may glimpse the tensions and attachments of Indonesia's Muslim art public as its artists and authorities sort out some of the aesthetic and ethical dimensions of Islamic art.

In the remainder of this essay, I discuss two episodes from the recent history of Islamic visual culture in Indonesia. Both took place during my decadelong ethnographic collaboration with Indonesian painter A. D. Pirous as he negotiated, and I explored, the cultural politics of contemporary Indonesian Islamic art. ${ }^{7}$ Both 
episodes reveal popular anxiety over the use of Arabic and Qur'anic calligraphy on different kinds of surfaces — paintings, women's fashion, T-shirts, and pages of a mushaf (or Qur'anic codex). Seyyed Hossein Nasr (1987:18-19), among many others, has argued that Qur'anic calligraphy enjoys a special privilege in Islamic communities as the visual embodiment of divine revelation, as "the geometry of the spirit," and as a talisman with a power and agency all its own. Indeed, Sheila S. Blair and Jonathan M. Bloom declare that the study of "calligraphy is vital to understanding the visual world of Islamic art and how it differs from other traditions" (2003:169). Yet a very general point I wish to make is that the art historical literature largely obscures problems in the making of Qur' anic art. Most classical art historical studies focus on the selection, style, and function of Qur'anic inscriptions in architecture (mosques, tombs), metal work (coins, vessels), ceramics, and woodwork, as well as in manuscripts and codices, and do not deeply explore debates or controversies over Qur'anic art. ${ }^{8}$ Studies of contemporary Qur'anic painting also largely pass over the predicaments of using Qur' anic verse as a pictorial sign. ${ }^{9}$

In exploring such predicaments, I follow Mitchell (2005:123-144) and take the view that episodes of alarm and panic over "offending" displays of Qur'anic art may give us important clues into the energies and ideologies of local and transnational Muslim art publics. Although I touch on questions of censorship, I am more concerned about the ethics surrounding Qur'anic visual art. In this respect, my work complements lines of argument developed by Charles Hirschkind (2006) in his study of the "Qur'anically tuned body" and the ethical sensibilities that Muslims cultivate through Qur'anic recitation, prayer, and listening to cassette sermons.

\section{THE LAGERFELD CONTROVERSY OF JANUARY 1994}

The story began in Paris on Saturday evening, January 15, 1994, as Karl Lagerfeld unveiled his spring couture collection for the fashion house, Chanel. ${ }^{10}$ Supermodel Claudia Schiffer paraded down the catwalk in a strapless, low-cut, black bustier decorated with a panel of Arabic script written out in gray pearl embroidery. ${ }^{11}$ Three days later, the Jakarta daily newspaper, Republika, handed over a Reuters snapshot of Schiffer in the bustier to the head of the Indonesian Council of Islamic Scholars (MUI), the ultraconservative K. H. Hasan Basri. The Arabic writing on the bustier was a phrase found in two verses of the Qur'an (QS 36 Ya Sin:21; and QS 6 Al An'am:82). It read, from right to left, and from quite low on the model's abdomen upward past her hips and waist, and along the contours of her bust: wa hum muhtaduun, "and they are rightly guided" (see Figure 1). The act 


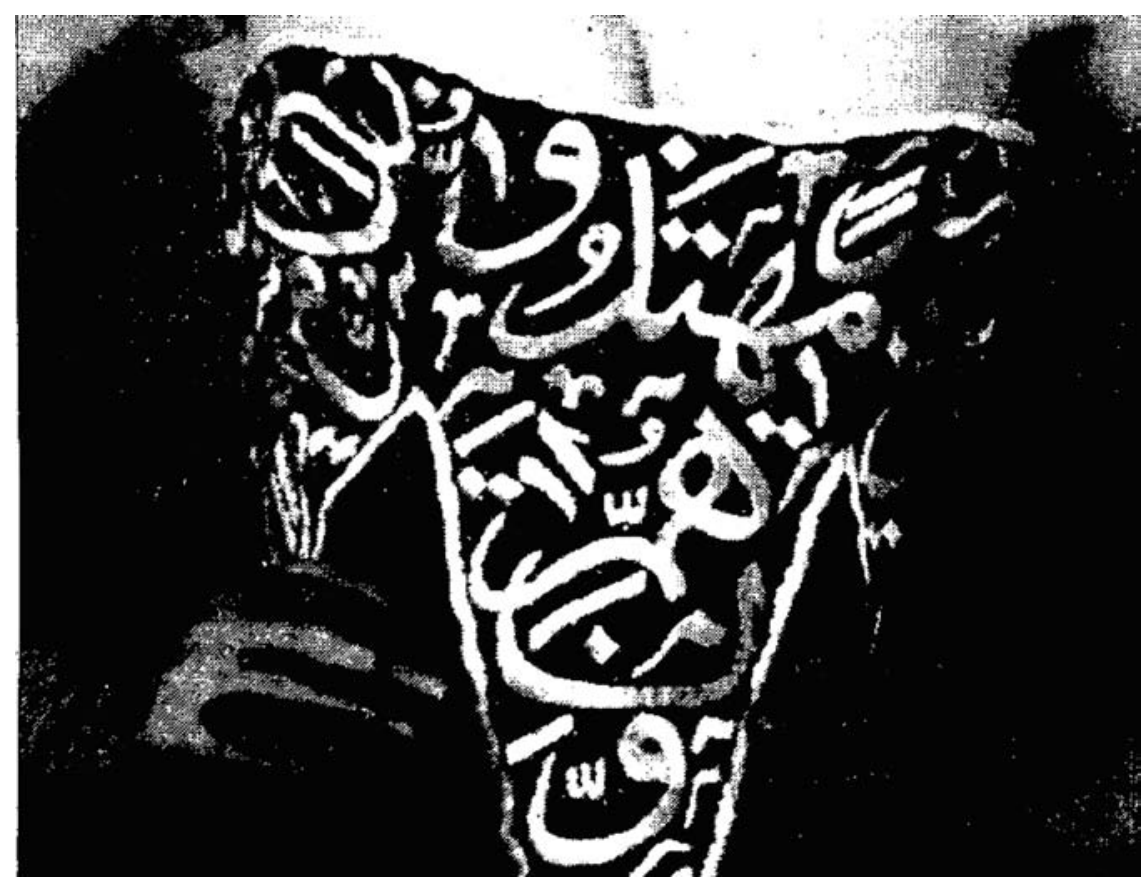

FIGURE 1. Detail from an unattributed photo of the offending Lagerfeld bustier that appeared in the Brisbane Courier-Mail, Saturday January 22, 1994.

of reading the script thus guided one's eyes upward along Schiffer's torso to the décolleté display of her shoulders and bust. In effect, both the passage and the act of reading it mimicked the primary purpose of the bustier — pushing up the bust.

“This is clearly an insult," said Basri (Republika 1994a). "To use the Qur'an just as one pleases?" Republika reported that Basri had deep suspicions about the design, believing that it was carefully planned to insult the global Islamic community and sprung from envy over the growth of Islam in Germany and the West (both Lagerfeld and Schiffer are German). This particular ulama, I should be careful to note, did not reflect mainstream Muslim sentiment in Indonesia, but the views of the DDII (Dewan Da'wah Islamiyah Indonesia, the Indonesian Council for Islamic Prosleytization) and KISDI (Komite Indonesia untuk Solidaritas dengan Dunia Islam, the Indonesian Committee for Solidarity with the Islamic World), two organizations who cast moderate and liberal Muslims as dupes too Westernized and too foolish to grasp global threats to the faith (Robert Hefner, personal communication, 2008). Basri persuaded MUI (a quasiofficial body that was founded by the Soeharto regime in 1975 for issuing fatwa) to file a protest with the German Embassy, and called for Muslims to speak up and boycott Lagerfeld 
designs in Indonesia. At the same time, he cautioned the Indonesian ummat that this provocation was intended to goad Muslims toward violence, and make it easy for the West to portray the ummat as destructive and terrorist, "just like [Samuel] Huntington's theories did" (Republika 1994a).

Republika (1994b) also had a few fashion designers weigh in. "If this is true that it uses sacred verse," said designer Ramli, "Karl's work is too vulgar." Ramli was especially bothered that Schiffer's cleavage was on clear display. "This time Karl went beyond creative. This work is a humiliating provocation, even if he didn't mean to insult us." Designer Ida Royani viewed things much as Basri did: "My feeling is that there is no way he didn't know the meaning of the verse that was written on the dress. I suppose the guy who made it is not a Muslim, right? So, if he didn't know, then he was playing around filching stuff. He should have asked someone who was knowledgeable and had the expertise."

The Indonesian ulama were the first anywhere to lodge protest and it was picked up and reported by the press worldwide. Passages from the Qur'an also appeared on two other evening dresses in the show, but the bustier had all the attention. On January 20, Lagerfeld told reporters from Agence France-Presse that he was "extremely upset" that he had offended Muslims, saying that neither he nor the embroiderer had known it was a passage from the Qur'an or a holy text of any kind (Jakarta Post 1994; Republika 1994c). He went on to confess - with considerable petulance, according to one report - that he had taken the "Arabic design" from a book on the Taj Mahal, and had been "told it was from a love poem in memory of a maharani.” A spokesperson for Chanel explained that the designer had "no idea what the original meaning was. He was just interested in the design from an aesthetic point of view" (Republika 1994d). Chanel meanwhile arranged for the offending dresses to be burned, although it is clear that no one from the Muslim community in Indonesia or Europe sought anything more than a boycott of Lagerfeld designs. The general director of public relations for Chanel subsequently made public expression of regret: "We would like to officially apologize to the Islamic community and to let it be known that we have destroyed the dresses thus embroidered, as well as all the negatives of the photos taken of these dresses." A company spokesperson made further plea to photographers and television crews who had been at the show to return their negatives and videotapes, "or to solemnly swear that they will destroy them and in no case use them or circulate them for any reason." Chanel also let it be known that it was not giving in to pressure from Muslims, but had taken these steps "Only because we indeed want to respect Islamic peoples. We don't want to hurt anyone's feelings.” 
Matters simmered on a global scale for a few days. Chalking up Lagerfeld's "mistake" as the result of "creative enthusiasm," the president of Chanel met with the rector of the Muslim Institute at the Mosque of Paris to repeat the company's apologies and have them relayed to Muslims around the world. Threats had been received and bodyguards were assigned to Lagerfeld and Schiffer (who, coincidentally, was now in Bali). The Brisbane Courier-Mail, the Jerusalem Post, and Egypt's Al-Waqf, among other newspapers, ignored Chanel's plea to pull photos from circulation and ran stories and images of Schiffer in the bustier. (Even Tempo, the Indonesian weekly, would run a photo of the bustier in its January 29 issue; but see below.) Muammar Qaddafi, the religious affairs committee of the Egyptian parliament, and various other Muslim bodies from around the world condemned Chanel for its insensitivity and provocation. A Muslim cleric from Brisbane questioned Lagerfeld's sincerity: "I do not believe they used the words unwittingly - it has been done to cause trouble or to annoy Muslims. They could have used common words in Arabic lettering but instead chose a verse from our most sacred book. Even we are not able to touch the Holy Qur'an without performing the proper ablutions first" (Brisbane Courier-Mail 1994).

A week after the Indonesian ulama filed protest, the incident began to fade from view. French and British newspapers had had the chance to throw in a few digs at Lagerfeld and make light of the controversy with headlines like "Blasphemous Bodices," "Satanic Corsets," "Satanic Breasts," and other references to the Rushdie Affair of 1989. As for Muslims around the world, the matter appears to have come to a close when the rector of the Muslim Institute in Paris accepted Chanel's apology and said that "God alone could forgive" Lagerfeld for inexcusably associating the Qur'an with a model's bust.

One of the most obvious and general lessons here is that clerics and scholars, rather than artists and designers, appear to wield preeminent authority in matters involving the Qur'an. Another is that Muslim art publics do not restrict their interests to the works and projects of Muslim artists alone, but take it upon themselves to weigh in on the visual arts whenever they impinge on religious concerns. Third, the Lagerfeld controversy obliges us to acknowledge that these authorities and art publics are enmeshed in transnational networks of solidarity and debate, such that they may not only view themselves as part of a global Islamic community, but also seek a platform to speak for its interests or to act on behalf of the common good of Muslims everywhere (cf. Salvatore 2007:49-51). At the same time, we will do well to take note of the national institutional structures within which these authorities acted. Basri and the MUI filed a protest through state diplomatic channels 
(reportedly, to Lagerfeld and Schiffer's Germany, not to Chanel's France), and called for an Indonesian market boycott of Lagerfeld designs (not that there were a lot available domestically). Just as these Indonesian clerics ignited global outrage through their domestic state and market, so too did other Muslim authorities respond as leaders of national religious bodies. Chanel, meanwhile, did not avail itself of state diplomatic channels, but appealed to a Muslim institution with great prestige and visibility in France. Thus, we see how in 1994 national spheres of Muslim religious authority and international media networks (many with national homes) meshed in way that would give the Lagerfeld affair broader, global import. The dynamics were much the same 12 years later during the Danish cartoon controversy of 2006, except that cyberspace communications - which were comparatively undeveloped and inaccessible in 1994 greatly amplified the speed and intensity of alarm and debate.

In the meantime, some reflection - and detective work - on the details of the incident may shed light on how the pictorial and verbal dimensions of written Qur'anic Arabic play into ethical concerns and anxieties. First, some detective work. Lee Yanowitch (1994), reporting on the show for Reuters on January 15, wrote that "Lagerfeld has been delving into antiquity for recent inspiration" and that the catwalk featured a tree-shaded pyramid. Orientalist fantasies and visual allusions to the eroticism of the East were a major theme in the show; for this reason I think it was no coincidence that Lagerfeld had picked up the design from a book on the Taj Mahal. Lagerfeld claims to have been oblivious to the Qur'anic sources for the inlaid, thuluth-style calligraphy on the monument. Grasping that the Taj Mahal was built as a mausoleum and shrine to immortalize Shah Jahan's love for his deceased wife, the princess Mumtaz Mahal, Lagerfeld substituted the purpose of the architectural whole for the meaning and function of an ornamental part. The calligraphic ornamentation on the Taj Mahal does not include QS 6 Al An'am, only QS 36, Ya Sin, a surah traditionally read over the dead or dying. It is clear, then, that the verse from which Lagerfeld lifted the phrase was QS 36:21: "Follow those who do not ask for any recompense of you, and who are rightly guided" (see Figure 2). This passage appears on the south arch (and main entrance) of the tomb (Begley and Desai 1989: plates 26, 27, 105, and 137), and nothing in its placement or inscription suggests formal affinities with the shape, support, and upward thrust of a bustier. ${ }^{12}$ More importantly, the Qur'anic Arabic copied from the Taj Mahal — although traditionally recited in tahlil rites for the dead or dying — no doubt made for Lagerfeld a suitable pictorial and Orientalist allusion to romance and passion. 


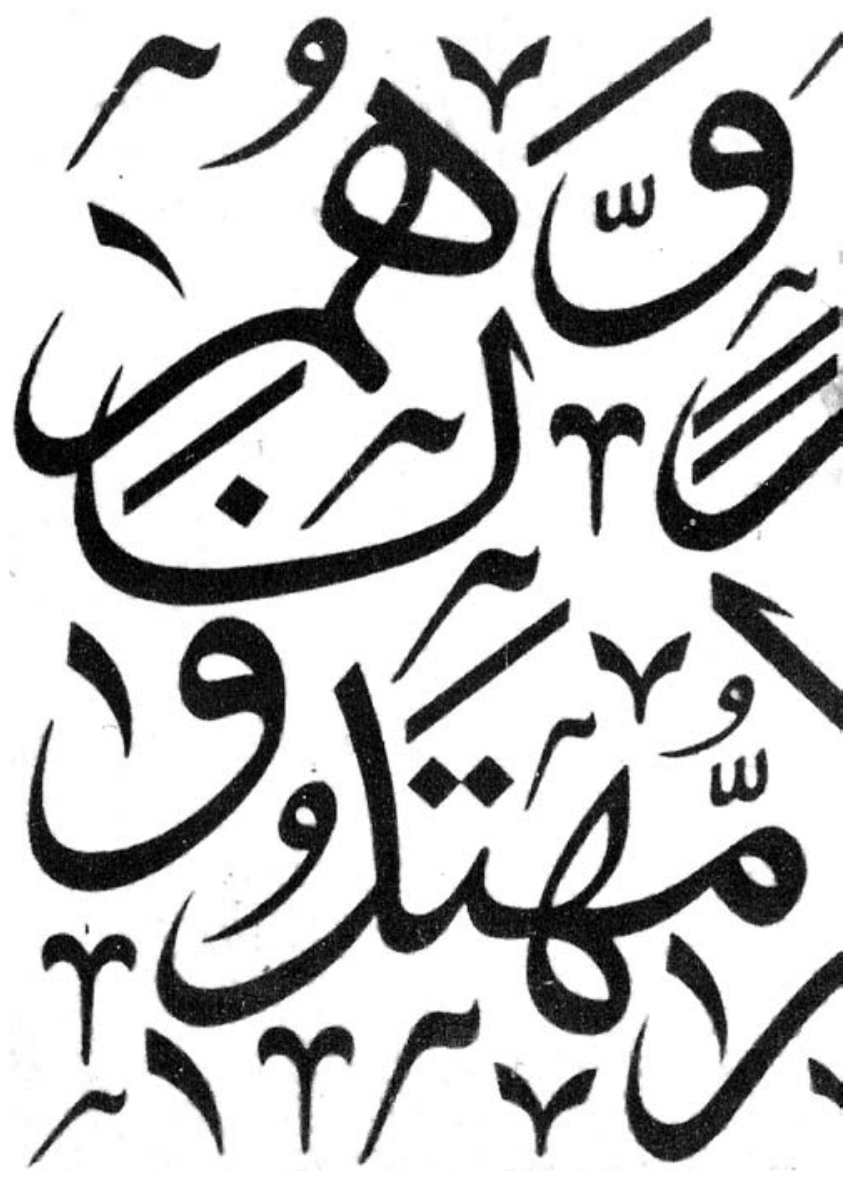

FIGURE 2. Detail from the Qur'anic inscription on the south arch and main entrance of the Taj Mahal, showing the part of QS 36 (Ya Sin) verse 21 that would appear on the Lagerfeld bustier. Source: Begley and Desai 1989:246, Plate 137.

Lifting Qur'anic verse from a photo or drawing of an architectural surface and placing it on an item of clothing did not come in for criticism. Its visual recitation across surfaces and materials - from jasper and marble by way of printed image to pearl-embroidered cloth - in and of itself did not appear to be a problem. Judging from the comments Muslims made to the press, the trouble stemmed from taking a fragment of Qur'anic verse - verse generally intended to lead to mindfulness of God - and placing it on clothing that immodestly bared a woman's shoulders and bust - a sight that for many would lead thoughts away from God toward worldly desires and carnal pleasures. Doing so amounted to desecration, a wrong handling of the Qur'an. Ethics had entered the picture, and raised questions about 
Lagerfeld's motivations. The problem, of course, relates to Lagerfeld's treatment of a material expressive form that is both pictorial and verbal. He looked at Qur' anic script and saw only an "Arabic design," and failed to read and find semantic value in the writing. Indeed, the defense put forward for Lagerfeld was that he saw in the Qur'anic calligraphy only pictorial or aesthetic value. In the eyes of some Muslims, this would be an ethical lapse, a willful and maybe stubborn refusal to read signs revealed by God. The ensuing difficulties in this case, I would suggest, were two: Bringing Qur'anic scripture into display with the nakedness and erotic provocation of a woman's bared bust and shoulders, to be sure. But second, teasing forth a reading of the verse that ran against its conventional, theologically grounded interpretation(s) and that saucily directed attention to the way one's eyes might be guided to the model's nakedness through the act of reading.

Chanel's decision to burn the dresses and to destroy photographic images of them seems aimed at slaking (and mimicking) the iconoclastic sensibilities characteristically imputed to Muslims. Again, no Muslim called for the destruction of the bustier, nor did any demand the destruction of the photos made of it. Chanel's choice of an iconoclastic gesture as the right thing to do owes much, I think, to the way its public relations outfit embraced broad, Orientalizing stereotypes of Muslim ethics and emotions. The company, of course, also had to present itself to other audiences. Rather than be seen as fearfully capitulating to pressure and protest from aggrieved Muslims, it defended its (blazing) sacrifice of high design as an ethical gesture of self-censorship, made out of regard for the feelings of others.

Meanwhile, some "modest” Muslim interest in the blasphemous bustier persisted. The Indonesian weekly, Tempo, published a cropped version of a Reuters photo of the bustier at the end of that January (Tempo 1994:47). Cropped from the photo were the model's face, shoulders, and most of her bust; the Qur'anic verse on the bustier appeared in its entirety. Cropping the photo so as to deface or decapitate the model would appear to accord with theological proscriptions on portrayals of animate beings, and so render the offending image powerless (see Flood 2002:643-648). Yet right next to it, sharing the same page and caption was another photo, this one showing Schiffer in a white miniskirt and a low-cut, torsohugging, sleeveless top. The layout for the story in Tempo suggests no small degree of ambivalence, or split consciousness, over how to depict an incident that joined fascination with the human figure together with sober reverence for Qur' anic verse and its orthographic figures.

Mitchell has written that "the intractability of offensive images stems [in part] from their tendency to take up residence on the frontlines of political and social 
conflicts ... as combatants, victims, and provocateurs" (2005:128). I leave the broader, global politics of the Lagerfeld controversy for another time and confine myself here to his infraction of Muslim ethics. In particular, I see in this episode broad Muslim concern for “good conduct” toward the Qur'an, Qur'anic script, and Qur'anic objects. Following the work of anthropologist Marilyn Strathern, the late Alfred Gell (1998) saw art objects as avatars of distributed personhood and subjectivity, and thus as vehicles of intention and agency. In Qur'anic verse, whatever its vocal or material manifestation, there is "divine presence," or "distributed divinity" if you like, in addition to distributed personhood and subjectivity of the one reciting or inscribing the divine message. For most Muslims, the ethical treatment of Qur'anic signifiers requires that artists and designers go beyond a "purely aesthetic point of view" and work in light of moral norms and semiotic ideologies for handling the sacred. ${ }^{13}$ Public culture in many, if not most, precincts of the West tolerate blasphemy on the part of artists and designers, but the public culture of the local and transnational ummat typically reflects their call or demand for the ethical formulation and display of Qur'anic art. Muslims, after all, are, as Niloofar Haeri (2003) reminds us, “custodians” of the Qur' an and its language (see also Fischer and Abedi 1990b:95-149). Desecration of the Qur'an - in part or whole - is an insult to God and the Prophet Muhammad, and should one or more authorities determine that desecration has occurred, any believer who heeds those authorities may feel hurt and spurred to custodial response. ${ }^{14}$

\section{THE PIROUS RETROSPECTIVE SHOW OF 2002}

I turn now to predicaments faced by Indonesian painter, A. D. Pirous, as he brought together work for his March 2002 career retrospective show at Jakarta's Galeri Nasional. ${ }^{15}$ Pirous (b. Meulaboh, Aceh, 1932, as Abdul Djalil Syaifuddin Piroes) is celebrated as a pioneer of Qur'anic calligraphic painting and of contemporary Indonesian Islamic art more generally. Unlike Indonesian artist Arahmaiani, whose critical feminist and postmodern sensibilities have led her from time to time to provocatively place a volume of the Qur' an beside lingerie, condoms, or bottles of Coca-Cola in her installations, ${ }^{16}$ Pirous has pursued a largely modernist, acclamatory art, glorifying Indonesia's Islamic cultural heritage through painting. Although his career reaches back into the 1950s, it was only in the 1970s that he took up an exploration of Islamic art, an exploration that drew from the abstract modernist styles of the West and indigenous iconographies from Indonesia (George 2007, in press). Beside establishing a reputation as one of Indonesia's leading painters, Pirous found public renown for mosque restorations and the calligraphic installations at 


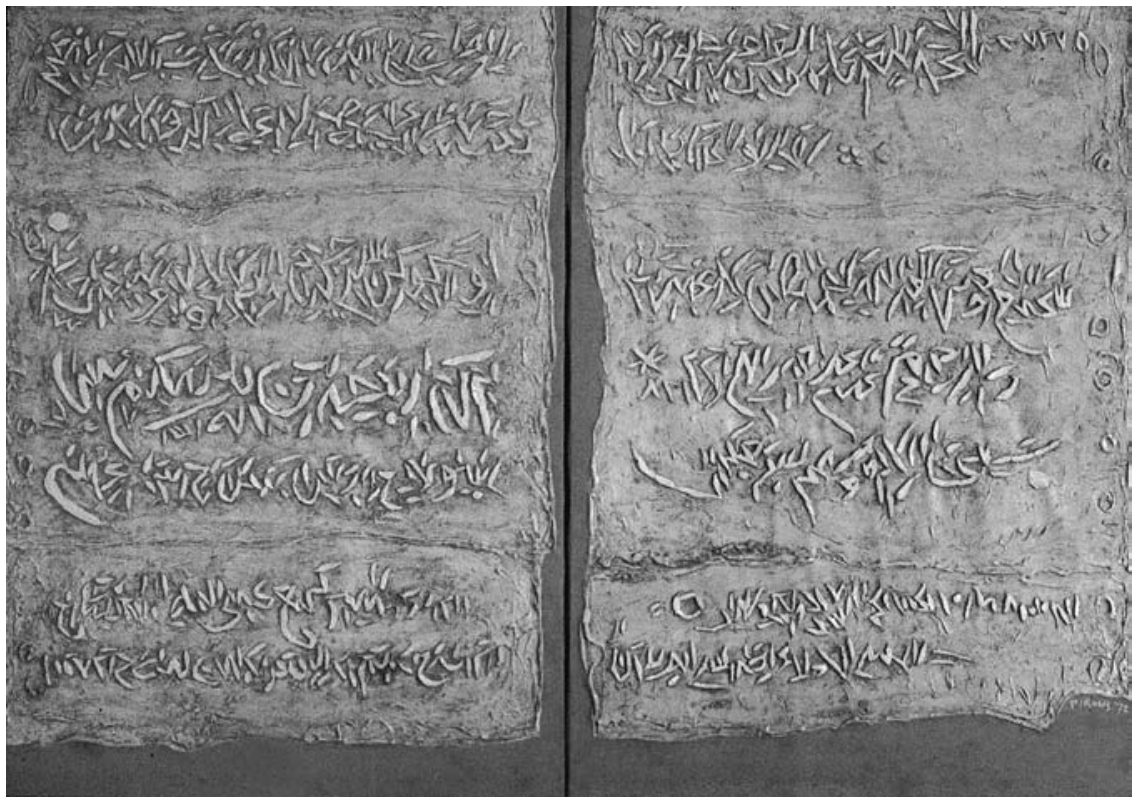

FIGURE 3. "White Writing” (Tulisan Putih) by A. D. Pirous, $1972.100 \times 180 \mathrm{~cm}$, marble paste, oil on canvas. Courtesy of the artist and Yayasan Serambi Pirous.

the national mosque in Jakarta, Mesjid Istiqlal; spearheading national Qur'anic art shows around the country and planning the two grand Istiqlal Festivals that showcased Indonesian arts and culture inspired by Islam; overseeing the production of the Al-Qur'an Mushaf Istiqlal; and serving as the Southeast Asian curator for an exhibit of contemporary Muslim art at the 1997 Venice Biennale.

Pirous has endured admonitions and expressions of doubt from ulama, clerics, and Muslim officials from the very start of his exploration of Islamic art, over 20 years before the Lagerfeld affair. His earliest faith-inflected works (1971-75) typically featured what he calls "expressive calligraphy" — highly abstract canvases with illegible Arabic-like figures, deformations of Arabic, or Arabic letters combined in a random way so as to thwart a reading beyond the figure of the character (see Figure 3). All bore titles that referred to inscribed objects of considerable antiquity ("Ancient Pillar" or "Archaic Manuscript") or to textual genres or styles of writing ("Epitaph II" or "Red Writing”). For Pirous, these works allowed him expressive freedom and maximum subjectivity while alluding to Qur' anic atmosphere and the miracle of divine revelation (wahyu). For many Indonesian exhibit-goers who viewed this work, the effect of looking upon images of something quite old, 
or something written this way and yet unreadable, was disturbing. The uncertain calligraphic figure — not quite Arabic, not quite Qur'anic — led to unease. ${ }^{17}$

Meanwhile, his explicitly Qur'anic painting, Sura Al-Fatihah (“The Prologue”), came in for criticism from an Acehnese ulama. The legible Qur'anic calligraphy in the painting had been damaged during installation. The ulama read some of the nicks to the canvas as improper "writing" and angrily accused Pirous of marring the Qur'an and playing around with it. Pirous brooded over the response to his shows, and ultimately resolved that he needed to put his artistic subjectivity in check. In a gesture of painterly judgment and self-censorship, he devoted himself in future work to the flawless calligraphic reinscription of Qur'anic verse. Doing so, he has said, has brought ethical pleasure to the viewer (George 2008:179-190; in press). But we should note, too, that this new painterly approach toward the Qur' anic became a modality of his own "good conduct" toward material expression of the divine message. That is, his treatment of Qur' anic orthography enhanced the beauty and meaning of the divine message through painterly means. At the same time, bringing Qur'anic Arabic onto his canvases was potentially a way of ethically enhancing the viewing experience of gallery-goers: looking at a work of art now included the reading or visual recitation of Qur'anic verse. ${ }^{18}$

Pirous has produced scores of Qur'anic paintings since 1975. They have earned him considerable popular and critical acclaim, and have been collected not only in Indonesia, but in Europe, Jordan, Saudi Arabia, and Bahrain. The flipside to his "Qur'anic posture” was that Pirous was now vulnerable to two new charges: "selling" the Qur'an — inasmuch as a painting is a commodity — and more commonly, religious proselytizing, or da'wah, an activity that conventionally falls to religious teachers and clerics versed in Qur'anic interpretation. ${ }^{19}$ The artist has usually shrugged off the first charge and disclaimed any interest in the second. Or as he often likes to say, "These paintings are just my spiritual notes," a view that professes indifference to the market or the gallery. Both these criticisms evince doubts about the ethics of placing Qur'anic calligraphy in abstract, modernist paintings. It is as if selling or displaying calligraphic paintings constitutes wrong handling of the Qur'an — one the crass and wrongful commodification of revelatory verse, the other the wielding of knowledge and authority that belongs properly to others. A third problem also posed itself: If a calligraphic figure is both a pictorial and verbal sign, what prevents a splash of paint on a Qur'anic painting from being "read" as a diacritic? Curators and collectors from the Middle East seemed quite relaxed about these issues, but the Indonesian art public seemed anxious about them. 
Much of that anxiety, in my view, stems from the fissured history and consciousness of Arabic in the Indonesian archipelago. With the exception of Arab minorities and Muslim religious scholars in the archipelago, Indonesians typically are not well versed in Arabic save for the utterances and professions required by Islam (e.g., the syahadat, or witness to faith). Many are able to read Arabic letters with the goal of reciting a text, but mere recitation of the phonemic values attached to the orthography does not assure grasp of a text's meaning. Familiarity with local or regional languages written in Arabic orthography has faded. As detailed by Henk Maier (2004:63-65) and Michael Laffan (2007), Dutch colonial scholars and administrators promoted the view that the Arabic orthographies used to write native Malay languages in the 17th and 18th centuries were inefficient, inappropriate, and defective. By the late 19th century, Dutch authorities worked to sever orthographic associations between Malay writing and the texts of a "dangerous" religion-Islam. The Roman alphabet came into ascendancy under colonial rule, driving Arabic orthography out of its place in everyday communication and sequestering it within religious practices. Key effects were two: one, heightened worries and doubts (especially in Sumatra) about locally produced mushaf - a fear that scrutiny would reveal errors in Qur'anic Arabic; and second, further fetishization of Arabic as a script of exceptional power and agency. Despite the reach of modernist Islam and improved rates of literacy in Classical (or Qur'anic) Arabic, many of today's Indonesians regard Arabic script with broad and uncontained reverence. As one Indonesian wag commented to me not long ago, "If an Indonesian buys a fish wrapped in a Jordanian newspaper, the paper will be carefully folded and kept on top of the family cabinet as an heirloom.”

Pirous has always had to work in light of this popular fetishization of Arabic in which every instance of Arabic writing is construed as sacral, or as the Qur'an itself. Attitudes like this perhaps assure that Pirous's calligraphic paintings will be greeted with some reverence, but they also place his artworks at risk of public scrutiny by self-appointed scripturalists (rather than the public authorities in the Department of Religious Affairs known as the Lajnah Pentashih, who inspect mushaf and published Qur'ans for errors). At the same time, Pirous has had to fend off religious authorities who see art and aesthetics as a threat to the integrity and purpose of the Qur'an. As Munawir Sjadzali, the Indonesian Minister of Religious Affairs, put it in 1992, commenting on design choices for the Al-Qur'an Mushaf Istiqlal, “The Qur'an should not be sacrificed for art” (Pelita 1992). Here again, some ethical questions turn on distinctions between pictorial and verbal dimensions of Qur'anic script. 
Planning for Pirous's career retrospective show in March 2002 put these anxieties and concerns into play once again. I was familiar with some of these anxieties from my collaboration with Pirous and planners for the 1995 Istiqlal Festival, but was surprised at how acute and enduring they were seven years later when I arrived in Bandung to help Pirous with his solo show. Beginning in February, Arabic experts on Pirous's curatorial team (Idris Pirous and Ilham Khoiri) began to examine all of Pirous's calligraphic paintings for errors in Qur'anic Arabic; errors in the Arabic orthography for the Indonesian Malay (called Jawi) or Acehnese on two dozen calligraphic paintings or so did not concern them. We also struggled over how to render Qur'anic Arabic in Roman orthography in a dual-language (Indonesian-English) artist's biography that I coauthored for the show (George and Mamannoor 2002). In short, Pirous had taken aboard his elder brother and Khoiri to work as an informal lajnah pentashih, charged with ensuring the accuracy of Qur'anic verse in the artist's paintings.

As that work went on, we busied ourselves, too, with promotional concerns and exhibit catalogs. Ilham Khoiri and Abdul Hadi W. M. prepared essays on Arabic calligraphy and calligraphic paintings. The leading suggestion for a promotional item was an exhibit T-shirt. Given Pirous's stature as pioneer of Qur' anic calligraphic painting, I pressed for a shirt featuring the artist's name in Arabic script. The planning team nixed the idea saying such a shirt might give offense. I did not see any Lagerfeldian problems and asked what the matter was. One of Pirous's sons-in-law - a product designer - explained that that someone might take offense were a person to wear the shirt into restrooms. Why? In popular understanding in Indonesia, he said, all Arabic script is sacred and should be handled so as to avoid defilement or desecration.

That same apprehensiveness and caution played a part in choosing which calligraphic works to include in the show. Of special concern were a number of paintings that Pirous calls his "Aceh Series" (George 2005:201-206; in press). These politically charged paintings, done between 1998 and 2002, reveal Pirous's outrage over revelations of state-sponsored atrocities in his home province of Aceh (which had been traumatized by Indonesian military occupation and counterinsurgency operations since 1989) and seem intended by the artist to haunt the Indonesian public conscience. All of these paintings featured calligraphic fragments from the Hikayat Prang Sabil ("The Chronicle of the Holy War"), the long and exhortative epic poem that recounts the impassioned anticolonial jihad waged by the Acehnese against Dutch oppressors during the late 19th and early 20th centuries. Appearing on or beside the hikayat passages are splatters and gashes of red pigment that we may 


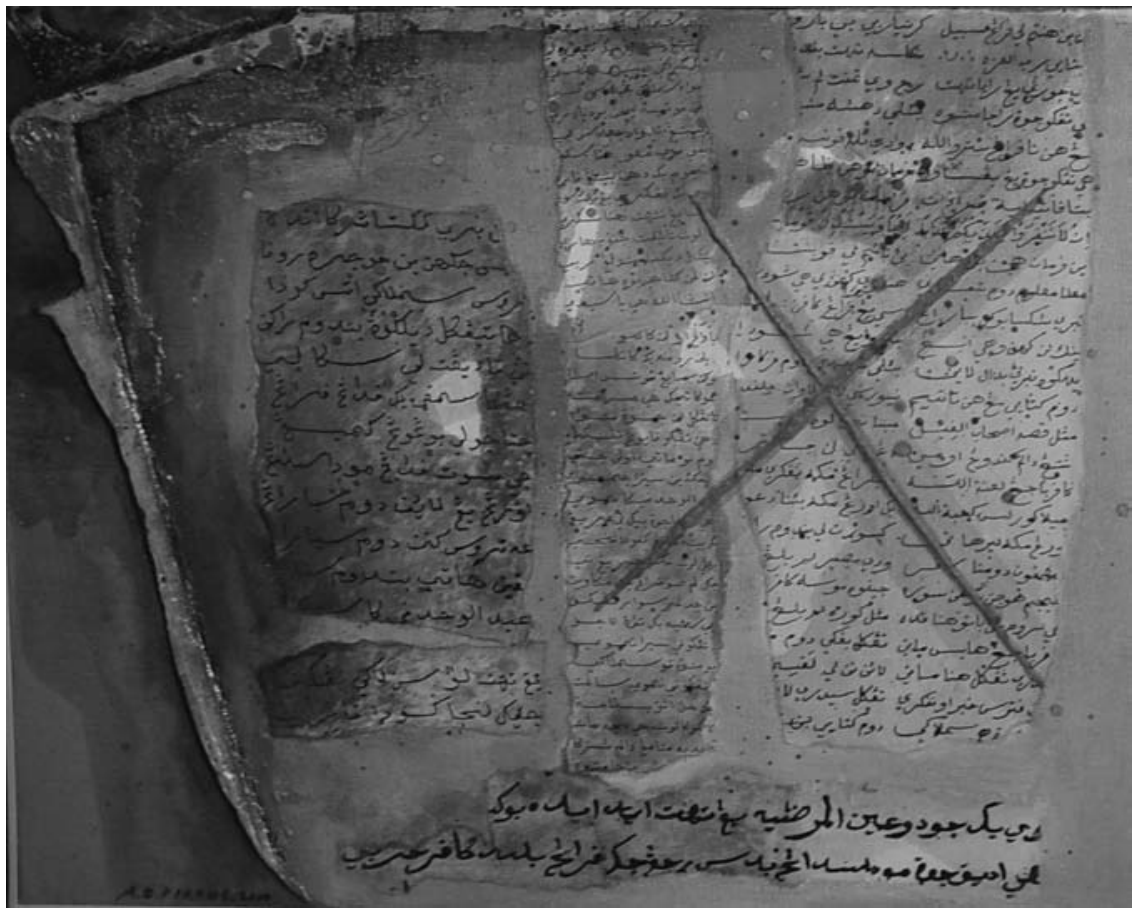

FIGURE 4. The painting from the "Aceh Series" that Pirous refrained from exhibiting in his 2002 retrospective show. By permission of the artist and Yayasan Serambi Pirous. Photograph by Kenneth M. George, 2002.

see as drops of blood or as viscous, oozing wounds. ${ }^{20}$ Pirous decided to showcase in the exhibit a dozen of the works from the Aceh Series. Nonetheless, the artist refrained from including in the show a small painting featuring a hikayat passage “wounded” by a viscous red, X-shaped gash (see Figure 4). Pirous was explicit about his worry, telling me that many Indonesian gallery-goers would regard this painting as a desecration of the Qur'an.

Over the course of a couple of weeks, Pirous and Ilham Khoiri found and set about correcting errors in a couple of paintings, including Hakim yang Sempurna itu Adalah Allah ("The Perfect Judge Is Allah), which features QS Al-Tin 95:8 (see Figure $5[\mathrm{~A}-\mathrm{C}])$. Idris, meanwhile, inspected the proofs for the artist's biography and spotted an error on a painting included as a color plate; Pirous corrected the calligraphy on the painting, and the color plate was carefully adjusted with Adobe Photoshop software. In the frantic weeks just before the exhibit was to open, Ilham was drawn to other tasks. Pirous sent more than 160 works to Jakarta for hanging in Galeri Nasional. There, on the eve of the exhibit's opening on March 11, Ilham 
discovered a rash of further errors in Qur'anic calligraphy. Taking up a penknife, brushes, and paints, Pirous altered more than a dozen paintings — some dating back over a decade, and virtually all having been exhibited many, many times without complaint (see Figure 6).

I was astonished at the degree of worry over the Qur'anic paintings, and must confess that I felt that altering the works was an act of iconoclasm - a mutilation. "But you've shown these before with no problem," I protested. Pirous and Ilham replied that the Indonesian Muslim ummat consists of three groups: "literalists" (yang literalis) who insist on standards for correct and precise transcriptive renderings of Qur'anic verse; “moderates” (yang moderat) who forgive or do not even perceive errors; and "liberals" (yang liberal) who put emphasis on the Qur'anic message,

A

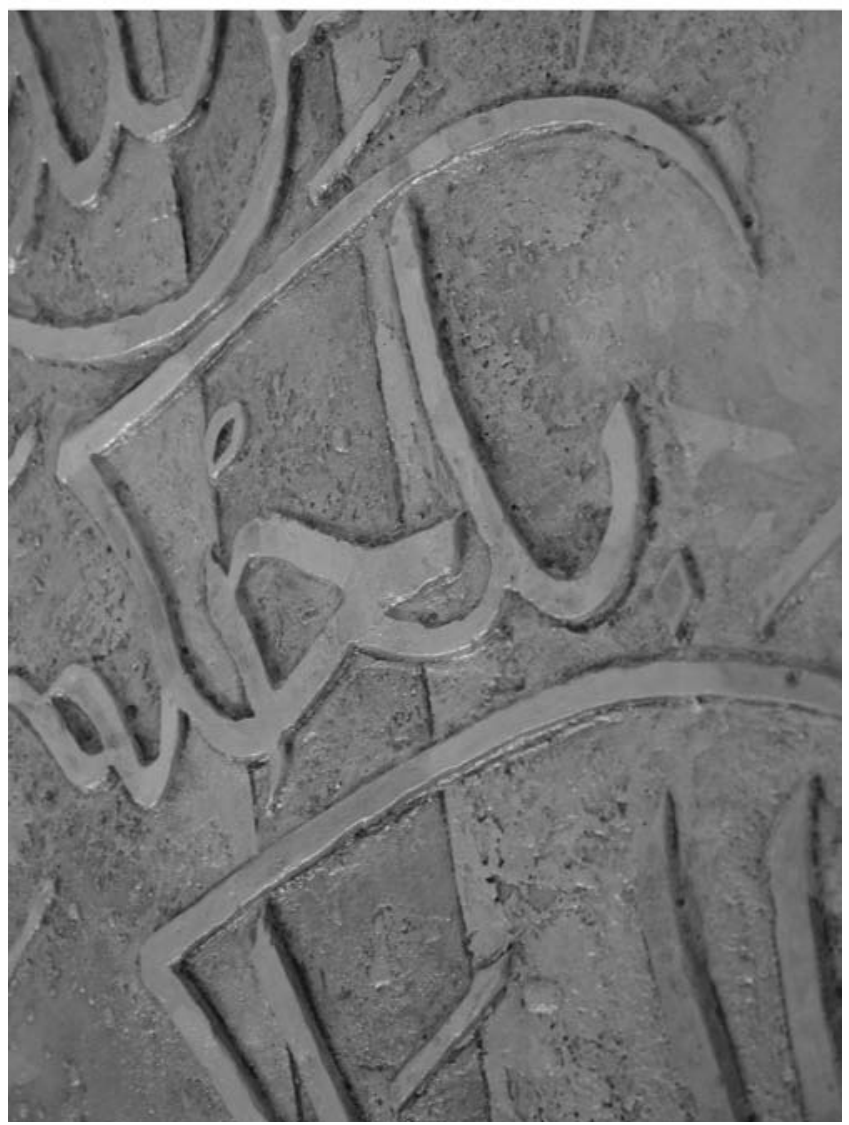

FIGURE 5 (A-C). Correcting the Qur'anic calligraphy from QS 95 (Al-Tin), verse 8 on "The Perfect Judge Is Allah" (Hakim yang Sempurna Itu Adalah Allah). Serambi Pirous Gallery, 


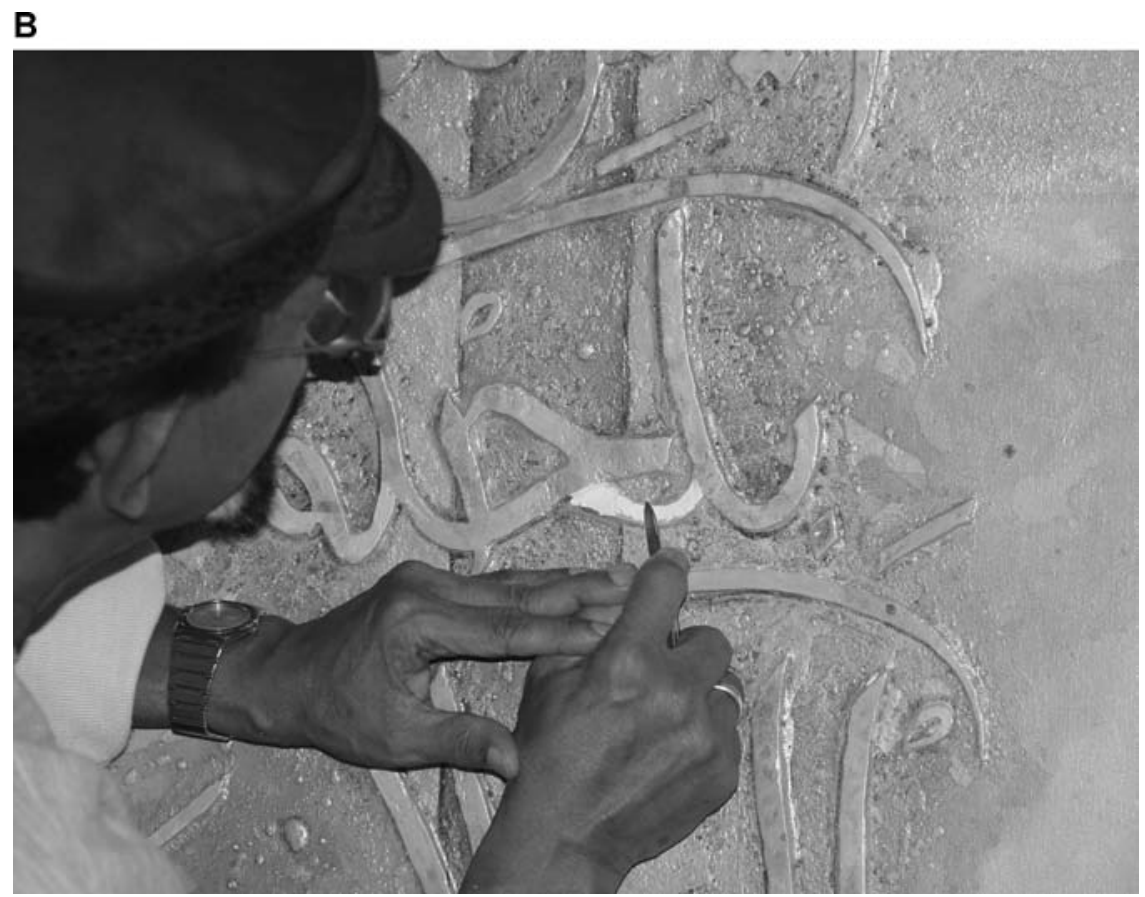

\section{C}

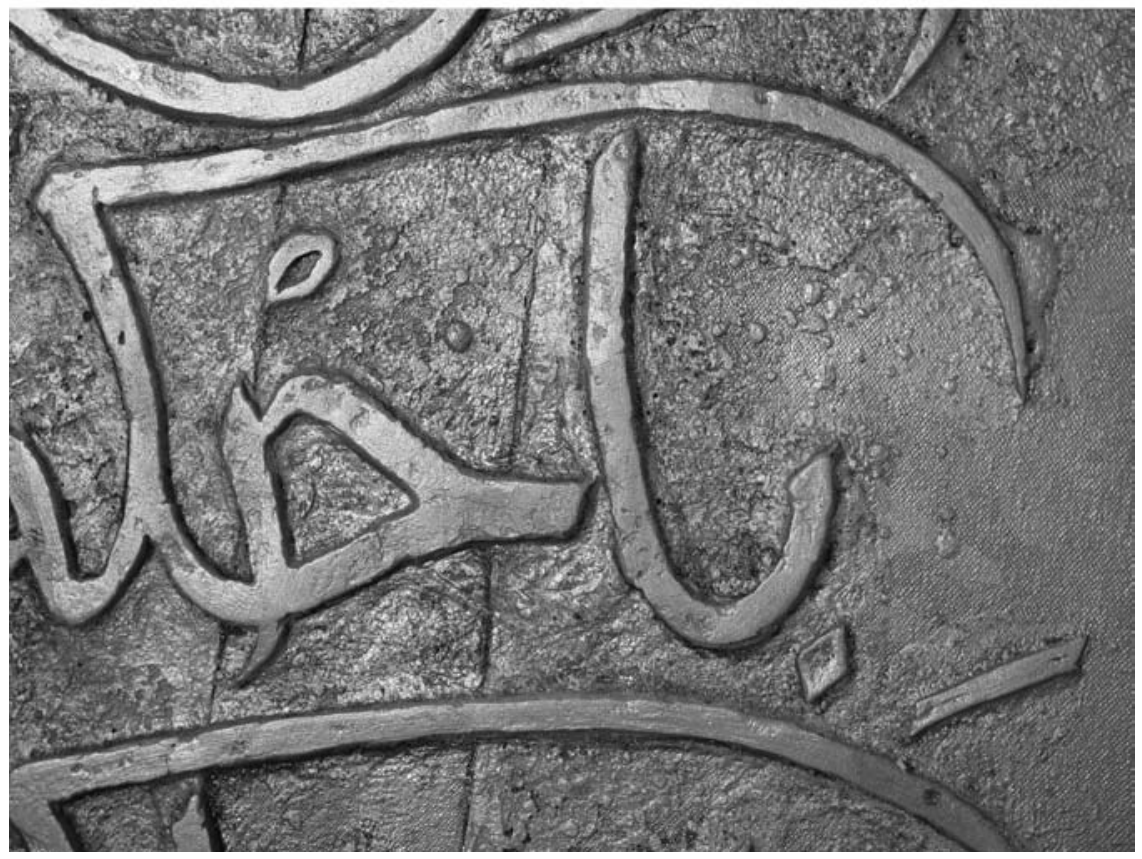

FIGURE 5. Continued. 


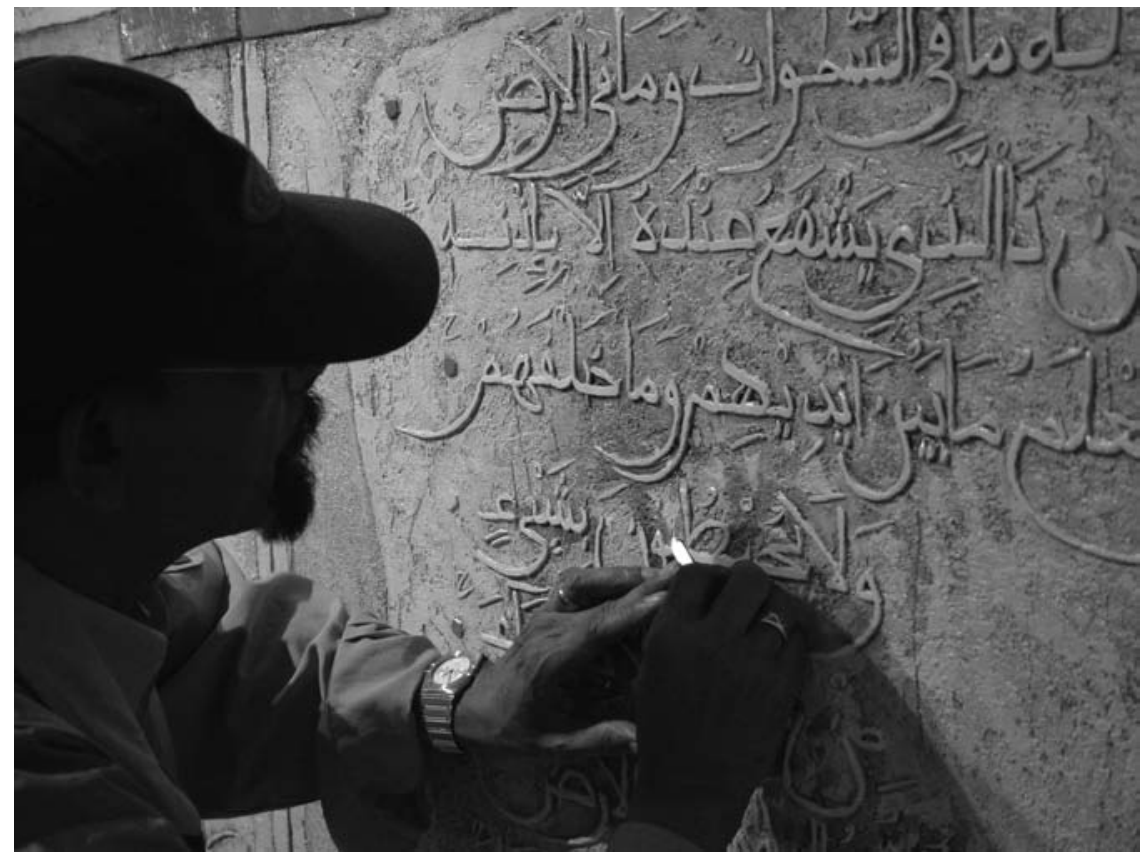

FIGURE 6. A. D. Pirous correcting the Qur'anic calligraphy on "The Verse of the Throne" (Ayat Kursi), March 10, 2002, at Galeri Nasional, Jakarta. The painting features QS 2 (Al-Baqarah), verse 255. Photograph by Kenneth $M$. George.

not its recitation or scriptural reproduction. Even though they acknowledged a plurality of views in the ummat on the matter of depicting the Qur'an, their practical response was acquiescence and concession to literalist hardliners and to those who fetishize Arabic orthography. They didn't want trouble from anyone, and sought only to please.

Yet in the years since that evening in Jakarta, I have come to see things a bit differently. On the one hand, I have come to understand that in his gesture of self-censorship Pirous was not mutilating his Qur'anic paintings, but perfecting them. ${ }^{21} \mathrm{He}$ was handling them ethically. On the other hand, I have come to doubt the extent or weight of popular Muslim protest in Indonesia's art world. Pirous and the curatorial team, I would emphasize, were worried not about the Muslim public at large - with its reputation for religious tolerance - but about "literalist" hardliners among the ulama who were indifferent to aesthetic concerns and saw in the Qur' an only immutable verbal signs. Their worry was not misplaced. Since 2002, the vigilantism and "morality racketeering" of Islamic street organizations, like Front Pembela Islam (FPI, the Islamic Defenders Front), have brought an 
element of threat and violence to the mix of forces interested in bringing Indonesia's art world into line with conservative Islamic views (Ingham 2005; Supangkat 2005; Wilson 2008). Although its member ulama are not uniformly conservative, MUI has declared secularism, liberalism, and pluralism un-Islamic, and in this way has helped legitimize FPI policing of cultural events.

\section{RELIGION, CULTURE, AND THE TWIN LIVES OF QUR'ANIC SIGNS}

I would argue that the twinned life of Qur' anic Arabic as a verbal and pictorial sign feeds many of the intractable anxieties and ideological clashes within and around Islamic visual culture. Despite the striking differences in their projects and outlook, what Pirous and Lagerfeld had in common was a grasp of the pictorial potency of Qur'anic Arabic. Both sought to tap or exploit that potency for aesthetic effect, but had to confront ethical concerns over Qur'anic Arabic and its legibility as a divine, immutable, and nonarbitrary verbal sign. Lagerfeld and Chanel claim to have missed the matter of legibility altogether. The Qur'anic Arabic on the bustier was intended as a pictorial icon of Oriental mystery and eroticism; belated recognition of its verbal capacities led to the iconoclastic burning of the offending fashion item as a gesture of ethical conduct. Pirous early on sought to avoid legibility altogether. He wished instead to pictorially reveal wahyu, the miraculous expression of divine power, through quasiorthographic form. The ulama and other conservative Muslim gallery-goers, however, desired or demanded legibility in this venture, even construing splashes of paint or nicks to a canvas as "writing." In yielding to these desires and demands as a gesture of good conduct toward the Qur'an, the artist had to contend with those who suspected him of usurping the role of religious teachers (i.e., practicing da'wah), as well as with those who saw all Arabic calligraphy as Qur'anic. Harboring no critical or transgressive views about the Qur' an, Pirous's ethical posture toward calligraphic art seems much in line with the broad contours of Islamic thought and conduct regarding the miracle and truth of the divine message, but it appears shaped, too, by fear of admonition and threat from religious hardliners. Bringing his ideas of religious orthodoxy to bear in his work as an artist may help shield him and his art from ultraconservative ulama and their street representatives. Doing so, however, does little to stop gallery-goers from looking for Qur'anic signifiers in all his calligraphic or expressive gestures. His painting is writing.

Many of the anxieties, aspirations, and fantasies that attach to Qur'anic calligraphy are by no means peculiar to the Muslim communities of Indonesia or the neighboring regions of Southeast Asia. The twin lives of Qur'anic signs animate 
much amulet making, sorcery, Sufi art, and meditational practice (dzikir) from Senegal to India, Indonesia, and Malaysia (see, e.g., Becker 2009; Farrer 2008; Flueckiger 2006; George 2008; Khan 2001; Roberts and Roberts 2003). Traditional arts in Turkey, Afghanistan, Iran, Iraq, Egypt, and other Muslim regions often used Qur'anic calligraphy to make the figurative shapes or outlines of birds, horses, lions, fish, fruits, and human faces (see Khan 2001). Modernist calligraphic painters in almost every Muslim country - painters such as Issam El-Said, Lalla Essaydi, Rashid Koraishi, Ahmad Moustafa, Wajih Nahle, Mehdi Qotbi, and Al-Said Hassan Shakir - have had to contend with or exploit the twin lives and sacralization of Arabic script (Ali 1997; Becker 2009; Khatibi and Sijelmassi 1995). At the same time, all these practices may run afoul of reformist or radical Islamic orthodoxies throughout Asia, Africa, and the Middle East. It is precisely calligraphy's intermingling of the pictorial and the verbal that also inclines many Muslim political-ethical reform movements to see messages everywhere in nature and everyday life, as did the Nigerian millenarian cult leader Muhammad Marwa Maitatsini, who informed followers that it was religiously unlawful to ride a bicycle because the form of a bicycle looks like the name of the Prophet Muhammad as it is written in Arabic (the letters mim-ha-mim-dal; see Hasan 1992:234-235).

The twin lives of Qur'anic Arabic take a different course in countries where Arabic is the dominant or official orthography for languages of the state, or the customary orthography for everyday vernaculars. The cultural politics of Arabic and Arabic orthography in most parts of the Middle East, North Africa, and Southwest Asia differ from those I have described for Indonesia. Language politics in these regions are tightly wound around questions about the relationship of Islam and Qur' anic Arabic to secularism, vernacularization, modernization, nationalism, and (for some) the lingering appeal of pan-Arabism. For example, as Niloofar Haeri (2003) has so subtly shown, Egyptians and citizens of other Arab states have long grappled with Classical Arabic - the sacred language of the Qur'an - as the language of the state, and as a language that no one speaks as a mother tongue. Relative to Indonesia, anxieties over Arabic orthography in places like Egypt or the non-Arab states of Iran and Pakistan are much relaxed for nearly everyone uses it in everyday communication. Pirous himself has commented on this to me. Collectors from Jordan and Saudi Arabia have purchased his paintings without raising questions over the calligraphy, and his five-meter, five-panel calligraphic painting Doa ("Prayer") belongs to the Al Hayat Museum in Bahrain's Beit AlQur' an ("House of the Qur'an"). While working with the museum representatives, Pirous expressed misgivings over the accuracy of the calligraphy in this Qur'anic 
painting. "Please don't worry," replied the buyers, "We know that Arabic isn't your language."

Having it both ways with Qur'anic Arabic — reading it verbally and seeing it pictorially — may be a guiding pursuit for Muslim artists like Pirous, but it also poses enduring ethical choices and predicaments for them as well. We can dispense with the idea that Muslims are theologically or culturally disposed toward iconoclasm in all times and places. In the cases presented here, iconoclastic sensibilities belonged largely to Westerners (Chanel representatives and me) preoccupied with how or whether to keep flawed displays of Qur'anic Arabic from offending Muslims. All the same, when conservative religious authorities and their agents on the street declare an image offensive, they raise the specter of iconoclasm as a retributive and potentially violent gesture of response. To be making "art" out of Qur'anic signifiers thus carries no small degree of risk, and not just for the material objects in question, but for artists and those displaying such work. ${ }^{22}$

This brings me back to Mitchell's claim that the intractability of offensive images springs in part from how they are enmeshed in broader kinds of social and political conflicts. Apropos to our understanding the debates and anxieties surrounding the verbal and pictorial aspects of Qur'anic Arabic, Mitchell counsels that "The point . . . is not to heal the split between words and image, but to see what interests and powers it serves" (1986:44). ${ }^{23}$ In the Indonesian context we need to look at this split in light of ideological and institutional contests over "religion" (agama) and "cultural arts" (seni budaya). The last 20 years have seen the growing Islamization of Indonesia's public culture. Indeed, much of what counts as Muslim politics in Indonesia is the effort to guide or control everyday comportment and cultural expression so as to be in accord with Islam (cf. Eickelman and Piscatori 1996; George 1998). Indonesia's art public, however, remains pluralistic and secular, responsible largely to itself and its ambitions for a place on the global stage, and guided by a cluster of elite art practitioners who speak for its interests, justify its artistic projects, and set the value of its products (cf. Bourdieu 1993; Crow 1985). These figures are predominantly Muslim, but typically modernist and postmodernist when it comes to their ambitions, critical sensibilities, and artistic judgment. Religious iconographies characteristically enter the picture as elements in a national or ethnic visual archive, detached from religious activity, and ready for painterly or artistic citation.

Not so Qur'anic calligraphy. Unlike some contemporary Indian artists who have turned images of Hindu gods and goddesses into "secular icons" (Zitzewitz 2008), most of Indonesia's Muslim artists take a respectful and custodial approach to 
the Qur'an, and show little inclination to desacralize it in service to other aesthetic projects. Ideas about religious orthodoxy appear to mediate their artistic practices. But let's not forget the Islamic clerics and scholars. What the Lagerfeld and Pirous episodes show us is that in Indonesia's art public, as in Islamic communities and networks more broadly, the principal and most vocal authorities on Qur'anic art are religious elites who have very little background in the arts but who figure centrally in the visual culture surrounding the Qur'an. ${ }^{24}$ As the leading custodial authorities on Qur'anic matters, it is they who are most anxious about guarding the sanctity of the Qur'an and preserving Qur'anic Arabic as an unblemished verbal sign. It is they who are most ideologically invested in keeping Qur' anic Arabic a religious concern, and putting a check to any expressive or pictorial manipulations of the Qur'an for worldly “cultural” or artistic ends.

Judging from what I know about Indonesia, artists and others have made little headway in establishing themselves as a new sort of authority on aesthetic and ethical dimensions of Qur'anic visual culture. The struggle in the late 1990s between the Ministry of Religious Affairs and the (former) Ministry of Education and Culture over the administration of the newly established Museum Bayt AlQur' an ("House of the Qur'an Museum") in Jakarta was but one further skirmish in the conflict over how to represent the Qur'an in its eye-catching materiality. The Ministry of Religious Affairs won control of the museum - for which Pirous was a prominent advocate and founding figure - only to watch a number of museum administrators and curatorial staff depart, and some artists to withdraw their work from the museum's collections. In short, artists interested in exploring the verbal and pictorial dimensions of Qur' anic material find themselves wedged or pulled between the rival discourses and ethical imperatives of "culture" and "religion." Custodial orthodoxy, if I may call it that, appears to be their common way of handling Qur'anic Arabic and reassuring religious authorities that its pictorial aspects will not violate or eclipse its language. Transgressions, both planned and unplanned, do of course occur.

Islamic themes and sensibilities are today at the hub of cultural expression in Indonesia. Books, magazines, films, television, music, fashion, text messaging, interior design, and accessories for the car and home all reflect the trend toward popular piety. As Islam leaves a more pronounced stamp on popular culture in Indonesia, various fields of cultural production have come increasingly under the watch of religious authorities and vigilante organizations. Indonesia's art world is no exception, and the Front Pembela Islam, among other vigilante groups, has been successful in disrupting or closing art events through opportunistic, arbitrary, 
and self-serving shows of power carried out in the name of God. In the wake of one such incident, Indonesian curator Jim Supangkat (2005) remarked that FPI's iconoclastic protests "lie beyond the platform of art" and should not be used to accuse Islam of opposing freedom of expression or of opposing art. As this and my earlier cases show, the ethical and ideological clashes over offending images signal broader struggles over art, secularism, and religion in the cauldron of global and national politics. More pointedly, Supangkat's remark warns us of violence and coercion taken up in the name of narrow orthodoxies. "There is no compulsion in matters of faith," says the Qur'an (QS 2:256). Will Indonesians be able to say the same in matters of art?

To close, then, this essay has portrayed art as an ethical venture and problem. Qur'anic art, or work construed as Qur'anic art, has special salience in this respect inasmuch as Muslims of vastly different social, cultural, and political backgrounds understand their custodianship of the Qur'an as key to the pursuit of a proper life. Artists might exploit the pictorial and verbal dimensions of Qur'anic Arabic for expressive ends belonging to other regimes of value, but in doing so they routinely must face the difficulty, if not the impossibility, of stripping these signs and their materiality from the context of divine revelation. Artists, we have seen, are but one group of arbiters concerned with what constitutes (or transgresses) the ethical treatment of Qur'anic verse as an art form. Clerics and others weigh in as well. Thus, we see contemporary Muslim art publics overlap with, and so include, networks of religious authorities who might otherwise have no familiarity with art world concerns. The power relations in these Muslim art publics are diverse, broadly inflected by particular national and institutional forces, and alert to the political, cultural, and ideological energies that animate today's transnational Muslim public sphere. I would argue that the intermingling of those Muslim art publics does not inherently advance a suffocating and uniform ultraconservatism across contemporary art worlds. To the contrary, that transcultural intermingling may encourage Muslims to sustain their fascination with and debate over the pleasures and power of art without fear of becoming unmoored from Qur'anic revelation.

\footnotetext{
ABSTRACT

What predicaments and crises are posed, whose interests are served, and what discourses are advanced when artists use the Qur'an for aesthetic projects? This essay throws light on some of the ethical and ideological energies that have animated today's Muslim art publics by looking at the anxiety and outcry in Indonesia's art world over the use of Qur'anic script in fashion and in painting. I argue that moments of panic or outrage may afford us a special glimpse of ethicopolitical claims as to what is or is not
} 
Islamically significant in the field of visual culture, and simultaneously reveal some of the power relations that shape national and global Muslim art publics. By looking at problems that have befallen designer Karl Lagerfeld and Indonesian painter A. D. Pirous, I suggest how a custodial ethics for handling Qur'anic Arabic has played into the hands of Muslim religious conservatives as they extend their authority into national and transnational art worlds, and more generally how Qur'anic art has become a space of struggle over the scope of secularism, religion, and culture. In doing so, I show ways in which the anthropology of art and the anthropology of Islam might fruitfully converge.

Keywords: ethics, art, fashion, censorship, visual culture, material culture, Qur'an, Islam, Indonesia, Arabic

\section{NOTES}

Acknowledgments. My research in Indonesia was funded by the Aga Khan Trust for Culture, the Social Science Research Council, and the Wenner-Gren Foundation for Anthropological Research. Background study and archival research were supported by the Institute for Advanced Study, the John Simon Guggenheim Foundation, the National Endowment for the Humanities, and the Center for Southeast Asian Studies at the University of Wisconsin-Madison. I thank them all for their support. I thank the University of Washington Press and the Aga Khan Program for Architecture at Harvard and MIT for permission to reproduce a photograph from W. E. Begley and Z. A. Desai, Taj Mahal: The Illumined Tomb (1989). I owe a special debt of thanks to A. D. Pirous and his family for their many years of friendship and collaboration. Although busy with her own research on Muslim German-Turkish return migrants, Susan Rottmann tracked down press reports related to the Lagerfeld scandal; I thank her for her marvelous and timely help. I am indebted, too, to Dustin Cowell, Iftikhar Dadi, Anna Gade, Robert Hefner, James Hoesterey, Carla Jones, Webb Keane, Paul Nadasdy, Kirin Narayan, Nora Taylor, Julia Thomas, Marina Welker, and Claire Wendland for their supportive and critical comments on drafts of this essay. Colleagues at the University of California, Los Angeles; the University of California, Riverside; and the University of British Columbia gave generous critical comment to seminar presentations of this essay; in particular I thank Muhammad Ali, Alexia Bloch, Tineke Hellwig, Doug Hollan, Julie Kruikshank, Abidin Kusno, René Lysloff, Peter Nabokov, Sally Ness, Sherry Ortner, Susan Ossman, Al Roberts, Polly Roberts, Adheesh Sathaye, Christina Schwenkel, and Deborah Wong. Finally, I thank CA Editors Kim and Mike Fortun for picking four superb anonymous reviewers for my manuscript. I could not ask for more helpful, generous, or engaged suggestions and comment from reviewers.

1. By "art public" I do not mean a mass audience for art. Following Thomas Crow (1985:5) I view an art public as that network of authorities, experts, and consumers who debate and justify artistic practices and put value on what those practices produce. A Muslim art public would be one such network whose members debate and justify art practices in light of (but not necessarily in conformity with) Islamic ideas and institutions.

2. Blair and Bloom (2003:153) argue that the very idea of "Islamic art" is a product of 19th- and 20th-century Western scholarship. Its Western origins notwithstanding, many contemporary Muslim artists today identify their work as "Islamic art."

3. See, for example, Ali 1997, 1989; Blair and Bloom 2003; Brend 1991; Dadi 2006; Grabar 1987; Irwin 1997; and Turgut 2007.

4. See Kratz 1986; and Maier 1987, 2004.

5. George 1998, 2005, 2007, 2008, and in press. See also Abdul Hadi W. M. 2000; Brenner 2005; Fealy and White 2008; Hefner 2000; Watson 2006:187-208; and Yustiono 1993.

6. For very recent developments, see Amrullah 2008; Avonius 2008; Fealy and White 2008; Jones 2007; Langenbach with Arahmaiani 2007; Smith-Hefner 2007; and van Heeren 2008. 
Widodo (2008) describes a "moral panic" among some Muslims who see media liberalization as a threat to Islamic values. This panic, argues Widodo, produced a "backlash" in which "concerned Muslims" worked energetically — and, paradoxically, within the context of media liberalization - to establish Islamic consumer and literary culture as a bulwark against immorality, hedonism, and Western-style secularism. Although he acknowledges the influential reach of the Islamic revival and the growth of Indonesia's Muslim middle class over the past decade and more, Widodo more or less gives us a picture of Indonesian Muslim writers and artists as reactionaries who are promoting a suspect mix of religion and capitalist economic value, rather than a sincere exploration of aesthetic and ethical concerns.

7. For various aspects of this collaboration, see George 1998, 2005, 2007, 2008, and in press. For key discussions on Pirous by others, see Spanjaard 1998:177-179, and Wright 1994:71-78.

8. See, for example, Blair and Bloom 2006; Gallop 2007; Grabar 2007; Suleman 2007; Tan 2007.

9. See, for example, Ali 1997; Dadi 2006; Jabra 1988; and Turgut 2007.

10. Source material for my account comes from articles in Republika (1994a, 1994b, 1994c, 1994d, 1994e) and the Jakarta Post (1994), and from numerous press service reports. Further press reports, articles, and some images may be found through Lexis-NexisAcademic.

11. Video footage may be found online at YouTube (2007).

12. It is clear that someone in the Lagerfeld atelier who had worked on the bustier was familiar with Arabic. The passage from QS 36:21 on the south arch of the Taj Mahal reads from top to bottom, but on the bustier it reads from bottom to top. Someone preserved the legibility of the Arabic, as well as the grammatical and orthographic integrity of the passage. The Lagerfeld atelier has designed clothes for Saudi clients, so we should not be surprised that someone in Lagerfeld's employ had command of written Arabic.

13. Compare with Keane 2009.

14. Verrips (2008) goes beyond W. J. T. Mitchell's analysis of offending images to argue that many believers experience sensorial and corporeal hurt when looking at blasphemous or sacrilegious art.

15. See the exhibition book by George and Mamannoor (2002) and George (in press).

16. Arahmaiani's use of the Qur'an and Arabic orthography in her 1994 show, "Sex, Religion, and Coca Cola," offended Himpunan Mahasiswa Indonesia (the Indonesian Muslim College Student Association) and led some of its members to remove one of her paintings and some items from an installation in the exhibit (Datuin 2000:68; Poshyananda 1996:43, 53). Others threatened her with hostile publicity, beatings, or death. See also Langenbach with Arahmaiani 2007.

17. The unease of gallery-goers may not have been so uniform. Citing work by Benedict Anderson and Nancy Florida, Astri Wright (1994:74) describes a popular interpretive tradition in Java in which texts or syllables have meaning and power without necessarily being comprehensible. For other esoteric views toward Qur'anic calligraphy and orthographic symbolism, see Grabar 1992; Khan 2001; Khatibi and Sijelmassi 1995; Leaman 2004; Nasr 1987; Osborn 2008:103148; and Schimmel 1984.

18. I thank Anna Gade for suggesting that I underscore this point. See also Grabar 1992:47-118.

19. See George (in press) for details on how some Indonesian Muslims have seen Pirous's paintings as exercises in da' wah or as commodifications of divine truth.

20. It is worth noting that in the eyes of the artist and our curatorial team the painterly iconography of blood did not amount to a desecration of Arabic. Of course, pictorial signs do not speak, but have meanings projected into or onto them. I have never talked to Pirous about it, but my hunch is that the "blood" in these paintings would conventionally be regarded as sacrificial blood, or the blood shed in jihad, not the spilled blood of infidels or any inadvertent and unexpected splashes of animal or menstrual blood. The blood of martyrs shed in jihad is not regarded as polluting.

21. Compare with Gade (2004) on perfecting Qur'anic recitation as a way of playing at orthodoxy.

22. Making art out of any sacred images and signifiers almost always poses risk and difficulties. For example, Myers (2002) discusses anxieties about and restrictions on the circulation and 
display of Australian Aboriginal art as it entered cosmopolitan frameworks of contemporary fine art. See also Becker (2009) on the possibilities for Arabic calligraphy in Morocco.

23. See also Mitchell's work on public art and violence, and on representation and responsibility in Picture Theory (1994).

24. Jessica Winegar (2008) reports that two popular television preachers in Egypt have begun to encourage Muslims to make art to become closer to God. Note that it is not contemporary Egyptian artists who have called for "Islamic art" but religious authorities who see art as a vehicle for da'wah.

Editor's Note: Cultural Anthropology has published other essays on Islam and creative expression. These essays include Anne Meneley's "Fashions and Fundamentalisms in Fin-de-Siècle Yemen: Chador Barbie and Islamic Socks" (2007), Katherine Pratt Ewing's "Between Cinema and Social Work: Diasporic Turkish Women and the (Dis)Pleasures of Hybridity" (2006), and Carolyn Rouse and Janet Hoskins's "Purity, Soul Food, and Sunni Islam: Explorations at the Intersection of Consumption and Resistance" (2004).

Cultural Anthropology has also published a number of essays on Indonesia. See Daromir Rudnyckyj's "Spiritual Economies: Islam and Neoliberalism in Contemporary Indonesia" (2009), Karen Strassler's "The Face of Money: Currency, Crisis, and Remediation in Post-Suharto Indonesia" (2009), and Marina Welker's "Corporate Security Begins in the Community: Mining, the Corporate Social Responsibility Industry, and Environmental Advocacy in Indonesia" (2009).

\section{REFERENCES CITED}

Abdul Hadi W. M.

2000 Islam: Cakrawala Estetik dan Budaya (Islam: Its aesthetic and cultural universe). Jakarta: Pustaka Firdaus.

Al-Azmeh, Aziz

1993 Islams and Modernities. New York: Verso.

Ali, Wijdan

1997 Modern Islamic Art: Development and Continuity. Gainesville: University Press of Florida.

Ali, Wijdan, ed.

1989 Contemporary Art from the Islamic World. London: Scorpion.

Amrullah, Eva F.

2008 Indonesian Muslim Fashions: Styles and Designs. ISIM Review 22:22-23.

Asad, Talal

2003 Formations of the Secular: Christianity, Islam, Modernity. Stanford: Stanford University Press.

Avonius, Leena

2008 The Ahmadiyya and Freedom of Religion in Indonesia. ISIM Review 22:48-49.

Becker, Cynthia J.

2009 Art, Self-Censorship, and Public Discourse. Contemporary Islam, February 28, 2009. Springer Science. Electronic document, http://www.springerlink.com/ index/91W4KMH43XT4U01H.pdf, accessed August 10, 2009.

Begley, W. E., and Z. A. Desai

1989 Taj Mahal: The Illumined Tomb. Seattle: University of Washington Press, and the Aga Khan Program for Islamic Architecture, Harvard and MIT.

Blair, Sheila, and Jonathan Bloom

2003 The Mirage of Islamic Art: Reflections on the Study of an Unwieldy Field. Art Bulletin 85(1):152-184.

2006 Inscriptions in Art and Architecture. In Cambridge Companion to the Qur'an. Jane Dammen McAuliffe, ed. Pp. 163-178. Cambridge: Cambridge University Press. 
Bourdieu, Pierre

1993 The Field Cultural Production: Essays on Art and literature. New York: Columbia University Press.

Brend, Barbara

1991 Islamic Art. Cambridge, MA: Harvard University Press.

Brenner, Suzanne

2005 Islam and Gender Politics in Late New Order Indonesia. In Spirited Politics: Religion and Public Life in Contemporary Southeast Asia. Andrew C. Willford and Kenneth M. George, eds. Pp. 93-118. Ithaca, NY: Southeast Asian Publications Series, Cornell.

Brisbane Courier-Mail

1994 Chanel "Sorry" for Dress that Offended Islam. Brisbane Courier-Mail, January 22.

Crow, Thomas E.

1985 Painters and Public Life in Eighteenth Century Paris. New Haven, CT: Yale University Press.

Dadi, Iftikhar

2006 Rethinking Calligraphic Modernism. In Discrepant Abstraction. Kobena Mercer, ed. Pp. 94-115. Cambridge, MA: Institute of International Visual Arts and MIT Press.

Datuin, Flaudette May V.

2000 Passing through Fire: Pain and Transformation in the Art of Arahmaiani. ART AsiaPacific 26:66-71.

Eickelman, Dale F., and James Piscatori

1996 Muslim Politics. Princeton: Princeton University Press.

Ewing, Katherine Pratt

1997 Arguing Sainthood: Modernity, Psychoanalysis, and Islam. Durham, NC: Duke University Press.

2006 Between Cinema and Social Work: Diasporic Turkish Women and the (Dis)Pleasures of Hybridity. Cultural Anthropology 21(2):265-294.

Farrer, D. S.

2008 The Healing Arts of the Malay Mystic. Visual Anthropology Review 24(1): 29-46.

Fealy, Greg, and Sally White, eds.

2008 Expressing Islam: Religious Life and Politics in Indonesia. Singapore: Institute for Southeast Asian Studies Press.

Fischer, Michael M. J.

2004 Mute Dreams, Blind Owls, and Dispersed Knowledges: Persian Poesis in the Transnational Circuitry. Durham, NC: Duke University Press.

2009 Iran and the Boomeranging Cartoon Wars: Can Public Spheres at Risk Ally with Public Spheres Yet to Be Achieved? Cultural Politics 5(1):27-62.

Fischer, Michael M. J., and Mehdi Abedi

1990a Bombay Talkies, the Word and the World: Salman Rushdie's Satanic Verses. Cultural Anthropology 5(2):107-159.

1990b Debating Muslims: Cultural Dialogues in Postmodernity and Tradition. Madison: University of Wisconsin Press.

Flood, Finnbarr Barry

2002 Between Cult and Culture: Bamiyan, Islamic Iconoclasm, and the Museum. Art Bulletin 84(4):641-659.

Flueckiger, Joyce Burkhalter

2006 In Amma's Healing Room: Gender and Vernacular Islam in South India.

Gade, Anna Bloomington: Indiana University Press.

2004 Perfection Makes Practice: Learning, Emotion, and the Recited Qur'an in Indonesia. Honolulu: University of Hawai'i Press. 
Gallop, Annabel Teh

2007 The Art of the Qur'an in Southeast Asia. In Word of God, Art of Man: The Qur'an and Its Creative Expressions. Fahmida Suleman, ed. Pp. 191-204. Oxford: Oxford University Press.

Gell, Alfred

1998 Art and Agency: An Anthropological Theory. Oxford: Oxford University Press. George, Kenneth M.

1998 Designs on Indonesia's Muslim Communities. Journal of Asian Studies 57(3):693-713.

2005 Picturing Aceh: Violence, Religion, and a Painter's Tale. In Spirited Politics: Religion and Public Life in Contemporary Southeast Asia. Andrew C. Willford and Kenneth M. George, eds. Pp. 185-208. Ithaca, NY: Southeast Asian Publications Series, Cornell.

2007 Art and Identity Politics: Nation, Religion, Ethnicity, Elsewhere. In Asian and Pacific Cosmopolitans: Self and Subject in Motion. Kathryn Robinson, ed. Pp. 37-59. New York: Palgrave.

2008 Ethical Pleasure, Visual Dzikir, and Artistic Subjectivity in Contemporary Indonesia. Material Religion 4(2):172-193.

In press Picturing Islam: Art and Ethics in a Muslim Lifeworld. Malden, MA: Wiley-Blackwell.

George, Kenneth M., and Mamannoor

2002 A. D. Pirous: Vision, Faith, and a Journey in Indonesian Art, 1955-2002. Bandung: Yayasan Serambi Pirous.

Grabar, Oleg

1987 The Formation of Islamic Art. New Haven, CT: Yale University Press.

1992 The Mediation of Ornament. Princeton: Princeton University Press

2007 The Qur'an as a Source of Artistic Inspiration. In Word of God, Art of Man: The Qur'an and Its Creative Expressions. Fahmida Suleman, ed. Pp. 27-39. Oxford: Oxford University Press.

Haeri, Niloofar

2003 Sacred Language, Ordinary People: Dilemmas of Culture and Politics in Egypt. New York: Palgrave.

Hasan, Salah M.

1992 Art and Islamic Literacy among the Hausa of Northern Nigeria. Lewiston, NY: Edwin Mellen.

Hefner, Robert W.

2000 Civil Islam: Muslims and Democratization in Indonesia. Princeton: Princeton University Press.

Hirschkind, Charles

2006 The Ethical Soundscape: Cassette Sermons and Islamic Counterpublics. New York: Columbia University Press.

Hoesterey, James B.

2009 Sufis and Self-Help Gurus: Islamic Psychology, Religious Authority, and Muslim Subjectivity in Contemporary Indonesia. Ph.D. dissertation, Department of Anthropology, University of Wisconsin-Madison. Ann Arbor: University Microfilms.

Ingham, Sue

2005 Pressure Points: Cultural Issues in Indonesian Biennials. Broadsheet 35(2):84-87.

Irwin, Robert

1997 Islamic Art in Context. New York: Harry N. Abrams.

Jabra, Jabra I.

1988 Calligraphy and Modern Art in the Arab World. In A Celebration of Life: Essays on Literature and Art. Pp. 163-176. Baghdad: Dar Al-Ma'mun.

Jakarta Post

1994 Lagerfeld “Upset” at Offending RI Muslims. Jakarta Post, January 21: 1. 
Jones, Carla

2007 Fashion and Faith in Urban Indonesia. Fashion Theory 11(2-3):211232.

Keane, Webb

2009 Freedom and Blasphemy: On Indonesian Press Bans and Danish Cartoons. Public Culture 21(1):47-76.

Khan, Gabriel Mandel

2001 Arabic Script: Styles, Variants, and Calligraphic Adaptations. New York: Abbeville.

Khatibi, Abdelkebir, and Mohammed Sijelmassi

1995 The Splendor of Islamic Calligraphy. Rev. and exp. edition. London: Thames and Hudson.

Kratz, E. U.

1986 Islamic Attitudes toward Modern Indonesian Literature. In Cultural Contact and Textual Interpretation (Verhandelingen van het Koninklijk Instituut voor Taal-, Land- en Volkenkunde 115). C. D. Grijns and S. O. Robson, eds.

Laffan, Michael Pp. 60-93. Leiden: Foris.

2007 "Another Andalusia": Images of Colonial Southeast Asia in Arabic Newspapers. Journal of Asian Studies 66(3):689-722.

Langenbach, Ray, with Arahmaiani

2007 Iconoclash. Broadsheet 36(3):176-181.

Leaman, Oliver

2004 Islamic Aesthetics: An Introduction. Edinburgh: Edinburgh University Press.

Mahmood, Saba

2005 The Politics of Piety: The Islamic Revival and the Feminist Subject. Princeton: Princeton University Press.

Maier, Henk

1987 Chairil Anwar's "Heritage: The Fear of Stultification": Another Side of Modern Indonesian Literature. Indonesia 43(April):1-29.

2004 We Are Playing Relatives: A Survey of Malay Writing (Verhandelingen van het Koninklijk Instituut voor Taal-, Land- en Volkenkunde 215). Leiden: KITLV.

Marcus, George E., and Fred R. Myers, eds.

1995 The Traffic in Culture: Refiguring Art and Anthropology. Berkeley: University of California Press.

Meneley, Anne

2007 Fashions and Fundamentalisms in Fin-de-Siècle Yemen: Chador Barbie and Islamic Socks. Cultural Anthropology 22(2):214-243.

Mitchell, W. J. T.

1986 Iconology: Image, Text, Ideology. Chicago: University of Chicago Press.

1994 Picture Theory: Essays on Verbal and Visual Representation. Chicago: University of Chicago Press.

2005 What Do Pictures Want? The Lives and Loves of Images. Chicago: University of Chicago Press.

Myers, Fred R.

2002 Painting Culture: The Making of an Aboriginal High Art. Durham, NC: Duke University Press.

Nasr, Seyyed Hossein

1987 Islamic Art and Spirituality. Albany: State University of New York Press.

Osborn, J. R. (Wayne)

2008 The Type of Calligraphy: Writing, Print, and the Technologies of the Arabic Alphabet. Ph.D. dissertation, Department of Communication, University of California, San Diego. 
Pelita

1992 Seni Mushaf Istiqlal: Jangan Korbankan Al-Quran Bacaan Umat (The art of the Istiqlal Mushaf: Don't sacrifice the Qur'an as the reading for the Muslim community). Pelita, August 12.

Poshyananda, Apinan

1996 Roaring Tigers, Desperate Dragons in Transition. In Traditions/Tensions: Contemporary Art in Asia. Pp. 23-53. New York: Asia Society Galleries.

Republika

1994a Peragaan Busana Bermotif Ayat Alquran. KH Hasan Basri: Jelas Penghinaan (Fashion design with Qur'anic motifs. K. H. Hasan Basri: A clear insult). Republika, January 19: 14.

1994b Peragaan Busana Bermotif Ayat Alquran. Vulgar, Pelecehan, dan Hentikan Membeli (Fashion design with Qur'anic motifs. Vulgarity, humiliation, and a boycott). Republika, January 19: 14.

1994c Lagerfeld Tarik Racangannya yang Lecehkan Umat Islam (Lagerfeld pulls his design that humiliated the Muslim community). Republika, January 21: 1.

1994d Chanel Minta Maaf kepada Umat Islam (Chanel apologizes to the Muslim community). Republika, January 22: 16.

1994e Claudia Schiffer Takut di-Salman Rushdie-kan (Claudia Schiffer is afraid of getting "Salman-Rushdied"). Republika, January 24: 1.

Roberts, Allen F., and Mary Nooter Roberts

2003 A Saint in the City: Sufi Arts of Urban Senegal. Los Angeles: Fowler Museum of Cultural History.

Rouse, Carolyn, and Janet Hoskins

2004 Purity, Soul Food, and Sunni Islam: Explorations at the Intersection of Consumption and Resistance. Cultural Anthropology 19(2):226-249.

Rudnyckyj, Daromir

2009 Spiritual Economies: Islam and Neoliberalism in Contemporary Indonesia. Cultural Anthropology 24(1):104-141.

Salvatore, Armando

2007 The Exit from a Westphalian Framing of Political Space and the Emergence of a Transnational Islamic Public. Theory, Culture and Society 24(4):45-52.

Schimmel, Annemarie

1984 Calligraphy and Islamic Culture. New York: New York University Press.

Silverstein, Brian

2008 Disciplines of Presence in Modern Turkey: Discourse, Companionship, and the Mass Mediation of Islamic Practice. Cultural Anthropology 23(1):118-153.

Smith-Hefner, Nancy

2007 Muslim Women and the Veil in Post-Soeharto Java. Journal of Asian Studies 66(2):389-420.

Spanjaard, Helena

1998 Het Ideaal van een Moderne Indonesische Schilderkunst, 1900-1995: De Creatie van een Nationale Culturelle Identiteit (The ideal of modern Indonesian painting, 1900-1995: The creation of a national cultural identity). Ph.D. dissertation, Faculty of Social Sciences, University of Leiden.

Strassler, Karen

2009 The Face of Money: Currency, Crisis, and Remediation in Post-Suharto Indonesia. Cultural Anthropology 24(1):68-103.

Suleman, Fahmida, ed.

2007 Word of God, Art of Man: The Qur'an and Its Creative Expressions. Oxford: Oxford University Press.

Supangkat, Jim

2005 Tolerating the Intolerant: An Interview. Broadsheet 35(2):85-87. Electronic document, http://universes-in-universe.org/eng/nafas/articles/2005/ cp_biennale_2005, accessed June 4, 2009. 
Tan, Huism

2007 Qur'anic Inscriptions on Woodcarvings form the Malay Peninsula. In Word of God, Art of Man: The Qur'an and Its Creative Expressions. Fahmida Suleman, ed. Pp. 205-216. Oxford: Oxford University Press.

Tempo

1994 Pokok dan Tokoh (Issues and people). Tempo, January 29: 47.

Thomas, Nicholas, and Diane Losche, eds.

1999 Double Vision: Art Histories and Colonial Histories in the Pacific. Cambridge: Cambridge University Press.

Turgut, Ayse

2007 Sacred Calligraphy in Contemporary Art. In Word of God, Art of Man: The Qur'an and Its Creative Expressions. Fahmida Suleman, ed. Pp. 217-226.

Oxford: Oxford University Press.

van Heeren, Katinka

2008 Cruelty, Ghosts, and Verses of Love. ISIM Review 22:20-21.

Verrips, Jojada

2008 Offending Art and the Sense of Touch. Material Religion 4(2):204-225.

Watson, C. W.

2006 Of Self and Injustice: Autobiography and Repression in Modern Indonesia (Verhandelingen van het Koninklijk Instituut voor Taal-, Land- en Volkenkunde 236). Leiden: KITLV.

Welker, Marina

2009 Corporate Security Begins in the Community: Mining, the Corporate Social Responsibility Industry, and Environmental Advocacy in Indonesia. Cultural Anthropology 24(1):142-179.

Widodo, Amrih

2008 Writing for God: Piety and Consumption in Popular Islam. Inside Indonesia 93 (August-October). Electronic document, http://insideindonesia.org/ content/view/1121/47/, accessed October 13, 2008.

Wilson, Ian Douglas

2008 "As Long as It's Halal": Islamic Preman in Jakarta. In Expressing Islam: Religious Life and Politics in Indonesia. Greg Fealy and Sally White, eds. Pp. 192-210. Singapore: Institute for Southeast Asian Studies Press.

Winegar, Jessica

2008 Purposeful Art: Between Television Preachers and the State. ISIM Review 22:28-29.

Wright, Astri.

1994 Soul, Spirit, and Mountain: Preoccupations of Contemporary Indonesian Painters. Oxford: Oxford University Press.

Yanowitch, Lee

1994 Naughty and Nice from Chanel. Reuters, January 15. Electronic document, http://www.lexis-nexis.com/, accessed October 8, 2008.

YouTube

2007 Claudia Schiffer in Satanic Dress by Karl Lagerfeld. Posted August 21, 2007. Electronic document, http://www.youtube.com/watch?v=EJyxAB8YRfY, accessed June 4, 2009.

Yustiono, ed.

1993 Islam dan Kebudayaan Indonesia: Dulu, Kini dan Esok (Islam and Indonesian culture: Yesterday, today, and tomorrow). Jakarta: Yayasan Festival Istiqlal.

Zitzewitz, Karin

2008 The Secular Icon: Secularist Practice and Indian Visual Culture. Visual Anthropology Review 24(1):12-28. 